\title{
Dendritic cells and scavenger macrophages in chronic inflammatory bowel disease
}

\author{
C A SELdenRIJK, H A DREXHAGE, S G M MEUWissen, S T PALS, \\ AND C J L M MEIJER \\ From the Department of Pathology, Department of Gastroenterology, Free University Hospital of Amsterdam, \\ The Netherlands.
}

SUMMARY We used enzyme (acid phosphatase [AP]) and immunohistochemical techniques and a set of monoclonal antibodies (CD11, CD5, CD4, CD19, CD8, OKIa), including two recently developed antibodies - for example, HECA-452 (specific for an adhesion molecule on high endothelial venules) and RFD1 (specific for 'active' human dendritic cells) to analyse the composition of the gut wall infiltrate of 10 well defined cases of chronic inflammatory bowel disease (CIBD) (six Crohn's disease (CD), four ulcerative colitis (UC)). Two polar forms in a spectrum of gut mononuclear phagocyte types $(\mathrm{CD11}+)$ were identified: at the one extreme scavenger macrophages with blunted projections (AP+, Heca-452-, RFD1-) and at the other extreme, dendritic cells with long dendritic cytoplasmic projections (AP-, Heca-452+, RFD1+). Dendritic cells were mainly found in highly organised lymphoid tissue present at the deeper layers in the gut wall (normal gut: underneath the muscularis mucosae and T-cell areas of lymph follicles [25-30 per follicle]; surrounding the broad zone of scavenger macrophages at the bottom of ulcers (CIBD) and fissures (CD) and in the lymphoid aggregates [25-30 dendritic cells per aggregate] adjacent to granulomas (CD)). These observations can be taken as evidence that exaggerated antigen handling and presentation and stimulation of the immune response takes place at these foci. The observation that scavenger macrophages were localised more superficial, as band like zones (normal gut: subepithelial; mainly surrounding ulcers (CIBD) and fissures (CD)) can be taken as evidence that at these spots the ingestion and degradation of foreign material takes place.

Class II MHC positive dendritic cells are important in the process of antigen presentation to lymphocytes and hence in the initiation of immune responses.' Dendritic cells were initially described in the T cell areas of lymph nodes and spleen. Some years later it was discovered that skin Langerhans cells also belonged to this group of cells. It is now appreciated that Langerhans cells travel from the skin to the draining lymph nodes through the lymphatics, transporting and exposing skin applied antigens on their surfaces $^{2-4} \mathrm{~A}$ similar antigen presenting cell system of dendritic cells occurs in the normal gut, particu-

Address for correspondence: Dr C A Seldenrijk. Academisch Ziekenhuis, Vrije Universiteit, Pathologisch Institut, De Boelelaan 1117. Postbus 7057. 1007 MB. Amsterdam, The Netherlands.

Accepted for publication 7 October 1988. larly the mucosa associated lymphoid tissue. ${ }^{5}$ Dendritic cells have not only been studied in normal immune responses, but also in inflammatory lesions such as rheumatoid arthritis and the granulomas of sarcoid, leprosy, and schistosomiasis. Large numbers of dendritic cells are present in such lesions and their in situ morphological relationship to lymphocytes has extensively been studied..$^{6-10}$

In situ morphological studies on the presence of dendritic cells in the normal gut wall and that of chronic inflammatory bowel disease (CIBD) focusing on their relationship to other lymphoid cells are scarce. ${ }^{11}$

The recent development of two monoclonal antibodies which can label dendritic cells are important for such in situ morphological studies: (1) Heca-452, which is specific for a highly glycosylated antigenic 
determinant (molecular weight 90 kilodalton) of a putative adhesion molecule expressed on high endothelial venules and on dendritic cells. ${ }^{12}{ }^{13}$ (2) RFD1, which identifies a unique class II major histocompatibility complex antigen ${ }^{14}$ expressed on 'active' dendritic cells present in immune lesions such as rheumatoid arthritis, lepromatous lepra and psoriasis. ${ }^{415}$

The aim of the present study is to analyse the composition of the gut wall infiltrate of 10 patients with CIBD, with special reference to the presence of dendritic cells and scavenger macrophages. In order to identify these cells we used a panel of monoclonal antibodies specific for monocytes/macrophage-like cells including HECA-452 and RFD1 in immunohistochemical techniques combined with acid phosphatase enzymehistochemistry.

\section{Methods}

PATIENTS

Ten patients with histologically, radiologically, endoscopically, and clinically typical Crohn's disease and ulcerative colitis were studied (Table 1). Six patients with Crohn's disease (four women, two men, mean age 28.5 years, range $20-43$ ). Four underwent an ilealcaecal resection, two a total colectomy. Four patients with ulcerative colitis (two women, two men, mean age 33.2 years, range 27-37). All had had a total colectomy. Controls consisted of four patients (three women, one man, mean age $55 \cdot 2$ years, range 44-77) suffering from gut diseases other than CIBD (Table 1). Two had had a right sided hemicolectomy, one a sigmoid resection (all for removal of an adenocarcinoma); one of the patients had a partial ileum resection for removal of a malignant fibrous histiocytoma. Control tissue specimens were taken from normal parts of the bowel unaffected by the malignancies.

\section{MATERIA LS}

Transmural tissue blocks (colonic as well as ileal) were taken (one block $/ 5 \mathrm{~cm}$ ) and, frozen in liquid nitrogen and stored at $-80^{\circ} \mathrm{C}$. Adjacent blocks, were fixed in $4 \%$ formalin solution, paraffin embedded, cut and stained ( $\mathrm{H}$ and $\mathrm{E})$. The surgical specimens fulfilled the macroscopical and microscopical criteria for CD and UC. ${ }^{16}{ }^{17}$ Because only typical cases of CD were included all the surgical specimens of patients with $\mathrm{CD}$ had fissures and granulomas. Six micrometres cryostat sections (10/frozen tissue block) were cut, air dried (overnight), fixed in acetone $(10 \mathrm{~min}$, $21^{\circ} \mathrm{C}$ ) and thereafter stored in a vacuum chamber $\left(-20^{\circ} \mathrm{C}\right.$ overnight $)$. Sections were stained with an indirect immunoperoxidase technique ${ }^{18}$ using the monoclonal antibodies listed in Table 2 . Sections
Table 1 Patient details

\begin{tabular}{cllll}
\hline Case & Sex & Age & Surgical therapy & Diagnosis \\
\hline 1 & F & 20 & Total colectomy & CD \\
2 & F & 22 & Ileocaecal resection & CD \\
3 & F & 43 & Ileocaecal resection & CD \\
4 & F & 22 & Ileocaecal resection & CD \\
5 & M & 38 & Ileocaecal resection & CD \\
6 & M & 26 & Total colectomy & CD \\
7 & M & 33 & Total colectomy & UC \\
8 & F & 27 & Total colectomy & UC \\
9 & F & 37 & Total colectomy & UC \\
10 & M & 36 & Total colectomy & UC \\
11 & F & 77 & Right hemicolectomy & Adenocarcinoma \\
12 & M & 44 & Sigmoid resection & Adenocarcinoma \\
13 & M & 42 & Right hemicolectomy & Adenocarcinoma \\
14 & M & 58 & Ileal segment resection & MFH \\
\hline
\end{tabular}

$\mathrm{F}=$ female $\mathbf{M}=$ male $\mathrm{CD}=$ Crohn's disease $\mathrm{UC}=$ ulcerative colitis; $\mathrm{MFH}=$ malignant fibrous histiocytoma.

Table 2 Characteristics of the monoclonal antibodies

\begin{tabular}{|c|c|c|c|}
\hline Antibody & $\begin{array}{l}\text { Cluster } \\
\text { differen- } \\
\text { tiation }\end{array}$ & Antigen & Specificity \\
\hline RFD1 (M)* & - & $\begin{array}{l}\text { Class II MHC } \\
\text { antigens }\end{array}$ & $\begin{array}{l}\text { 'Active' dendritic cel B } \\
\text { cell subsets }^{13}\end{array}$ \\
\hline $\begin{array}{l}\text { HECA-452 } \\
\text { (R) } \dagger\end{array}$ & - & gp90 & $\begin{array}{l}\text { High endothelial } \\
\text { venules, dendritic } \\
\text { cells }{ }^{1112}\end{array}$ \\
\hline Leu $1(\mathbf{M}) \ddagger$ & CD5 & T1 (p67) & $\begin{array}{l}95 \% \text { human } \\
\text { thymocytes, } 95 \% \\
\text { peripheral T- } \\
\text { lymphocytes, most } \\
\text { slg+ B-CLL cells, no } \\
\text { normal lymphocytes }\end{array}$ \\
\hline Leu $12(\mathrm{M}) \ddagger$ & CD19 & B cel (p95) & B lymphocytes ${ }^{27}$ \\
\hline Leu $3 a(M) \ddagger$ & CD4 & $\mathrm{T} 4(\mathrm{p} 55)$ & $\begin{array}{l}\text { Helper/inducer T- } \\
\text { subsets }^{2 \mathrm{x}}\end{array}$ \\
\hline RIV4 (M)§ & CD8 & T8 (p32-33) & $\begin{array}{l}\text { Suppressor/cytotoxic T } \\
\text { subsets }^{24}\end{array}$ \\
\hline OKIa (M)\| & - & $\begin{array}{l}\text { Class II MHC } \\
\text { antigens (p29- } \\
\text { p34) }\end{array}$ & $\begin{array}{l}\text { B cells, active T- } \\
\text { lymphocytes, } \\
\text { macrophages }\end{array}$ \\
\hline FK24 (M)ף & CD11 & C3bi receptor & $\begin{array}{l}\text { Monocytes and } \\
\text { macrophages }\end{array}$ \\
\hline
\end{tabular}

$\mathbf{M}=$ monoclonal raised in a mouse; $\mathbf{R}=$ monoclonal raised in rat. $\mathrm{CD}=$ cluster differentiation proposed at the 'Leucocyte Typing Conference' (Boston, MA, USA, 1984). *Poulter, London, UK;' †Duijvestijn, Amsterdam, The Netherlands; ${ }^{\prime \prime} \ddagger$ Becton Dickinson, CA, USA; §Rijksinstituut voor Volksgezondheid en Milieuhygiëne, The Netherlands; \|Ortho, NJ, USA; ๆMonosan/Sanbio, The Netherlands.

were incubated for 60 minutes at room temperature. To block the endogeneous peroxidase the sections were pretreated with $0.0075 \mathrm{U}$ glucoseoxidase (Sigma, St Louis, USA) in $0 \cdot 1 \mathrm{M}$ D-glucose (Darmstadt, Germany) in PBS for 30 minutes. The second step was a rabbit antimouse Ig labelled with horse radish peroxidase (Dakopatts, Copenhagen, 
Danmark, dilution of $1: 25,30 \mathrm{~min})$. For the rat monoclonal antibody (HECA-452) the second step consisted of a rabbit antirat Ig labelled with horseradish peroxidase (Dakopatts, Copenhagen, Denmark, dilution $40,30 \mathrm{~min})$. The sections were developed with diaminobenzidine (three $\min$ ) and counterstained with haematoxylin. A simultaneous detection of HECA-452 and intracytoplasmic acid phosphatase activity was done. The enzymehistochemical staining for acid phosphatase was done according to Burnstone. ${ }^{514}$ This acid phosphatase reaction was carried out after the immunohistochemical procedure.

\section{Results}

On the basis of (a) reactivity with the moab against the putative adhesion molecule identified by HECA452 , (b) reactivity with the moab against the special epitope of Class II MHC determinants identified by RFD1, and (c) the presence of the lysosomal enzyme acid phosphatase, and (d) shape, we were able to identify two large mononuclear phagocyte cells in the normal as well as in the diseased gut wall (Table 3 ). Both cell types were positive with CD11, a monoclonal antibody specific for $\mathrm{C} 3 \mathrm{bi}$ receptors indicating, that both cell types were of mononuclear phagocyte character.

The first cell type was a large cell (Table 3 ), which was strongly positive for the lysosomal enzyme AP. Though some expressed Class II MHC determinants (OKIa) the cells did not react with HECA-452 and RFD1. These cells often showed small blunted projections (Fig. 1A). Hence these cells had the phenotypic characteristics of a scavenger macrophage.

The second cell type (Table 3 ) showed strong reactivity with the moab OKIA, HECA-452, and RFD1 (Fig. 1B); however, practically no AP-activity was identified. Although the sape was difficult to judge (because of the use of frozen sections), long dendritic cytoplasmic projection were often identified. This cell type most likely represents the dendritic cell active in the handling and presentation of antigen.

These two mononuclear cell types formed the extremes of a spectrum of CD11 positive cells, which showed enzyme and immunohistochemical characteristics positioned in between these two polar forms: such intermediate cell types showed some forms of cytoplasmic protrusions, all had class II MHC determinants (OKIa), and the majority of these cells showed a weak reactivity with the moab HECA-452 and had some AP-activity. It is important to note that these cells did not react with the moab RFD1 (we further refer to such cells as 'undeterminate monocytoid cells').
Table 3 Staining characteristics of the dendritic cell and scavenger macrophage

\begin{tabular}{lll}
\hline Antibody & Dendritic cell & Scavenger macrophage \\
\hline CD11 & + & + \\
OKIa & + & + \\
HECA-452 & + & - \\
RFD1 & + & - \\
Enzyme: & & \\
AP & - & + \\
\hline
\end{tabular}

HEALTHY ILEUM AND COLON

Underneath the surface epithelium of the normal colon clusters of zonally arranged scavenger macrophages were found (Figs. 2 and 3a). These cells intermingled with a few dendritic cells. In the villi of the normal ileum such zonally arranged cells were also present but their numbers were lower (approximately two times lower as compared with colonic mucosa).

Deeper down in the lamina propria of the ileum and the colon a few scattered 'undeterminate monocytoid' cells were found, while just above the muscularis mucosae an occasional dendritic cell could be identified. These cells often formed small clusters in which also a few T-lymphocytes could be identified (Fig. 3a).

At the transition of the lamina propia and submucosa, in the area of the muscularis mucosae, an occasional lymphoid follicle was present (approximately two to three per $\mathrm{cm}$ bowel segment). The centre of such a follicle consisted of the well known 'tingible body' macrophages and B cells (CD19); this $B$ centre was surrounded by a rim of $T$ cells. In this $T$ cell area dendritic cells could clearly be identified (approximately 25-30 per lymphoid follicle) as well as some high endothelial venules, which were, like the dendritic cells, positive for the determinant recognised by the moab HECA-452 (Fig. 3a). The submucosa itself contained a few solitary scavenger macrophages and some 'undeterminate monocytoid cells', but dendritic were largely absent. In the muscularis propria dendritic cells could not be identified and, T- and B lymphocytes were almost absent.

C I B D

The bottom of the ulcers (both in CD and UC) and the fissures (only in $\mathrm{CD}$ ) consisted of a broad zone of densely packed scavenger macrophages, intermingled with numerous 'undeterminate monocytoid cells' (Fig. 3b). This inner zone of mononuclear phagocyte cells was in turn surrounded by an outer zone of cells predominantly consisting of T lympho- 


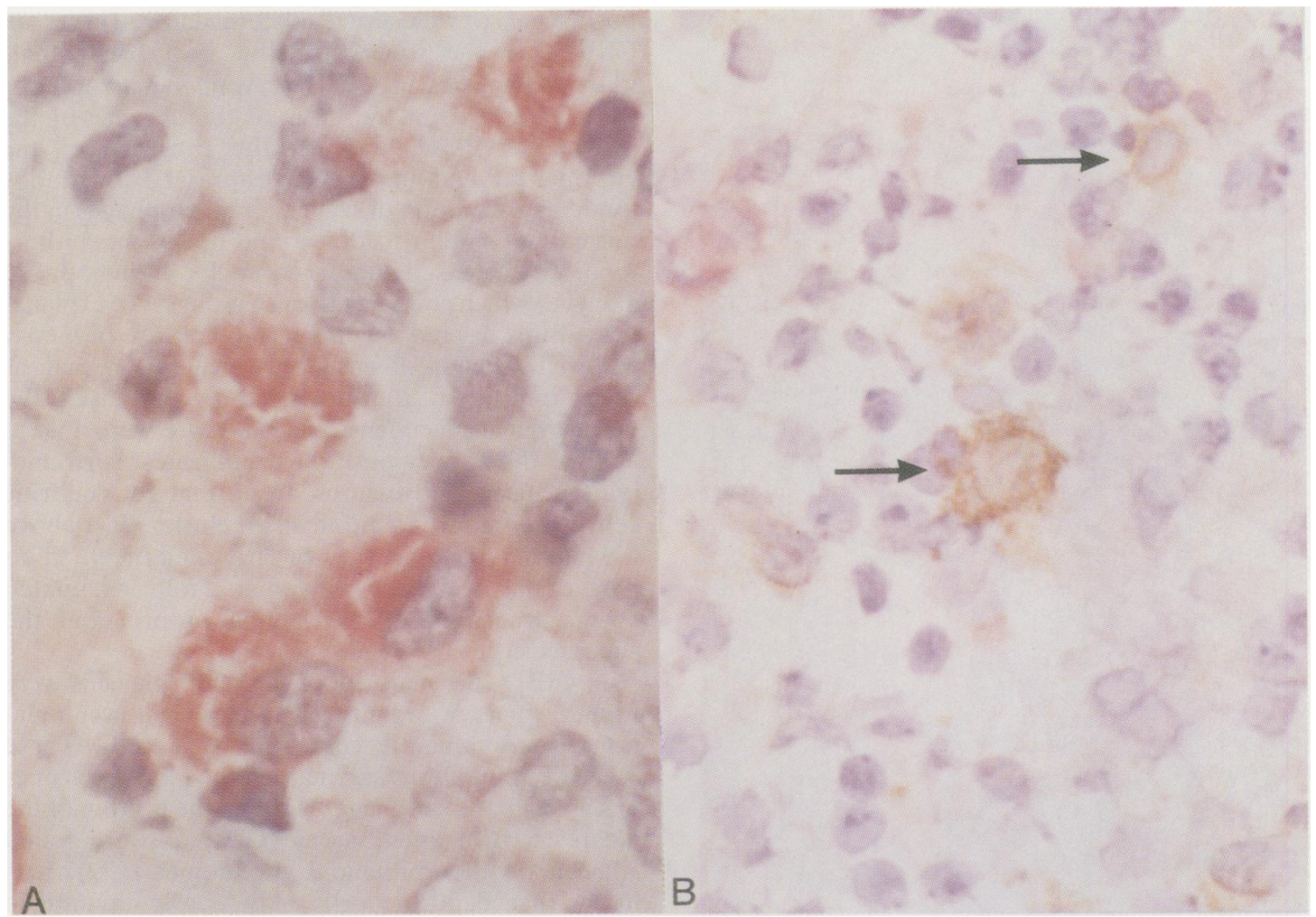

Fig 1 (A) Scavenger macrophage with small blunted projections (AP+, Heca-452-); (B) Dendritic cell with cytoplasmic protrusions (AP-, Heca-452+) showing contact with T lymphocytes. Immunoperoxidase double staining for AP and Heca-452.

cytes, with a $\mathrm{T}$ helper $(\mathrm{Th})$ to $\mathrm{T}$ suppressor/cytotoxic $(\mathrm{Ts} / \mathrm{c})$ ratio of $2: 1$. In between these $T$ cells of the outer zone a few dendritic cells could be identified, and some HECA-452 positive high endothelial venules were part of this area (Fig. 3b). Besides these structures a few B cells (CD19) as well some plasmacells were found in the outer zone, there was also an occasional a lymphoid follicle.

In $\mathrm{CD}$, the granulomas were localised transmurally, often along the draining lymphatics. The packed epitheloid cells forming the centre of such granulomas showed strong acid phosphatase activity; they did however not react with the moabs HECA452 and RFD1, which probably means that these cells are mainly involved in processes of degradation. Adjacent to or around these epithelioid cells accumulations of T lymphocytes were present. Several high endothelial venules positively staining with the moab HECA-452 were present in these T cell areas (Figs. $3 c, 4)$. The parts of the areas most closely positioned to the epitheloid cells predominantly consisted of $\mathrm{Th}$ cells intermingled with dendritic cells (approximately
25-30 per lymphoid aggregate); Ts/c cells were scarce (Th to Ts/c ratio of $6: 1$ ). The outer parts of the lymphocytic zones contained relatively higher numbers of Ts/c cells and Th to Ts/c to ratio's of 3:2$2: 2$ were found. A few B cells could also be identified in these parts, but plasmacells were absent. There were no remarkable differences in the composition of the infiltrate between ileal and colonic tissue in $\mathrm{CD}$. In UC, the number of lymphoid follicles at the transition of muscularis mucosae had increased (approximately six to eight follicles per $\mathrm{cm}$ bowel segment) compared with $\mathrm{CD}$ and normal subjects; however, the composition of the follicles was comparable with that of lymphoid follicles present in: the normal colon.

Both in $\mathrm{CD}$ and $\mathrm{UC}$, the remaining part of the swollen edematous submucosa contained large numbers of scavenger macrophages and 'undeterminate monocytoid cells' (four to five times as much as in healthy colon). These cells did not show any noteworthy contacts with other lymphoid cells present in this area. 


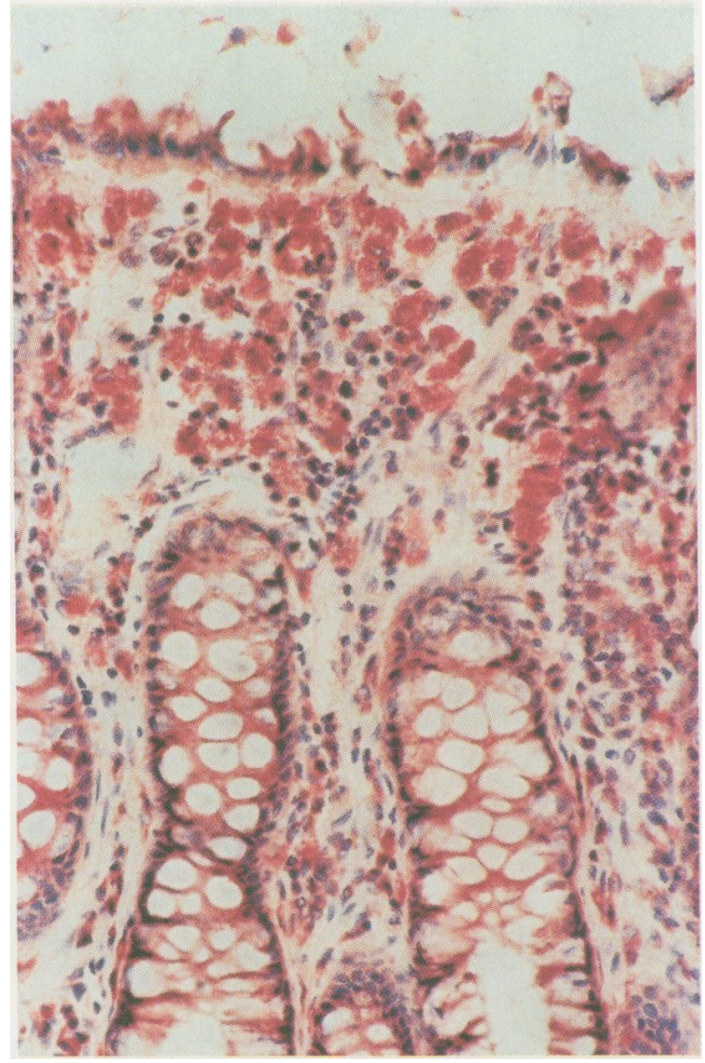

Fig 2 Normal colonic mucosa with clusters of zonally arranged scavenger macrophages underneath the surface epithelium. Immunoperoxidase staining for $A P$.

\section{Discussion}

In this immunohistochemical study on surgical specimens of normal gut and typical cases of CIBD, in which two recently developed morioclonal antibodies - that is, Heca-452 and RFD1 were included, we were able to distinguish a dendritic cell (OKIa+, $\mathrm{AP}-$, Heca-452+, RFD1+), and a scavenger macrophage (OKIa,+ AP + , Heca-452-, RFD1-) (Table 3).

In normal gut scavenger macrophages were predominantly found zonally arranged just underneath the enterocytes in both colon and ileum. In CD and UC scavenger macrophages were present in higher numbers, as compared with the normal gut. They were arranged in band like zones forming the bottom of the ulcers or fissures. It is likely that the zonally arranged macrophages represent a scavenging defence mechanism towards microbial agents or dietary substances, penetrating through small (in normal gut) or widespread mucosal defects (in case of CIBD). In the study of Selby et $a l^{11}$ on colonic mucosal biopsies of CIBD scavenger macrophages were identified on the basis of the absence of the enzyme ATP-ase, and on the presence of the enzymes AP and non-specific esterase. Though they found a distribution of scavenger macrophages in the normal gut similar to that found by us, the authors reported decreased numbers of such cells in both $C D$ and UC, which contrasts to our findings. An explanation of this discrepancy might be their use of biopsy material which necessarily only includes on analysis of the infiltrate of the superficial mucosal layer. We used surgical specimens, and therefore were able to analyse the deeper positioned infiltrates, surrounding the ulcers and fissures. In normal gut dendritic cells were mainly found in small clusters just above the muscularis mucosae, or just underneath it as parts of the $T$ cell zones of lymphoid follicles situated at the transition of the lamina propria and the submucosa.

In CIBD, the majority of the dendritic cells were found as part of organised lymphoid cell accumulations, predominantly consisting of $\mathrm{T}$ cells. These $T$ cell accumulations surrounded the band like zones of scavenger macrophages forming the bottom of the ulcers (CIBD) and fissures (CD), or were found adjacent to the epithelioid granulomas (CD). It is likely that dendritic cells play a role in antigen presentation to these $\mathrm{T}$ cells.

Immune granulomas, similar to those found in $\mathrm{CD}$, have been described in the lesions of tuberculoid leprosy, sarcoid and protozoan infections as schistosomiasis. ${ }^{75}$ The granulomas in these disorders are thought to be the result of an exaggerated, but intact $\mathrm{T}$-cell mediated immune reaction towards a persisting antigen of either unknown origin (sarcoid) or of microbial nature ( $M$ leprae, the nematode egg). It is tempting to speculate that the $\mathrm{T}$ cell granulomas in $C D$ are likewise engaged in the handling and/or degradation of a persisting antigen. A microbial antigen which has recently come into the focus of attention is that of $M$ paratuberculosis, ${ }^{20}$ which organism has been recently cultured from gut tissues of patients with CD. ${ }^{2122}$ Other antigens that might play a role are those of commensal microbes - for example, $E$ coli 014 , those of dietary origen such as cow's milk proteins, or autoantigens such as colonic epithelial cells. ${ }^{23-25}$

Selby et al in their study on CIBD identified dendritic cells on the basis of strong ATP-ase activity in combination with a weak AP and non-specific esterase activity." In contrast with our results, they found such cells to be present in CIBD in equal numbers as in the normal gut wall. In colonic mucosa of patients with CIBD, however, such cells were 


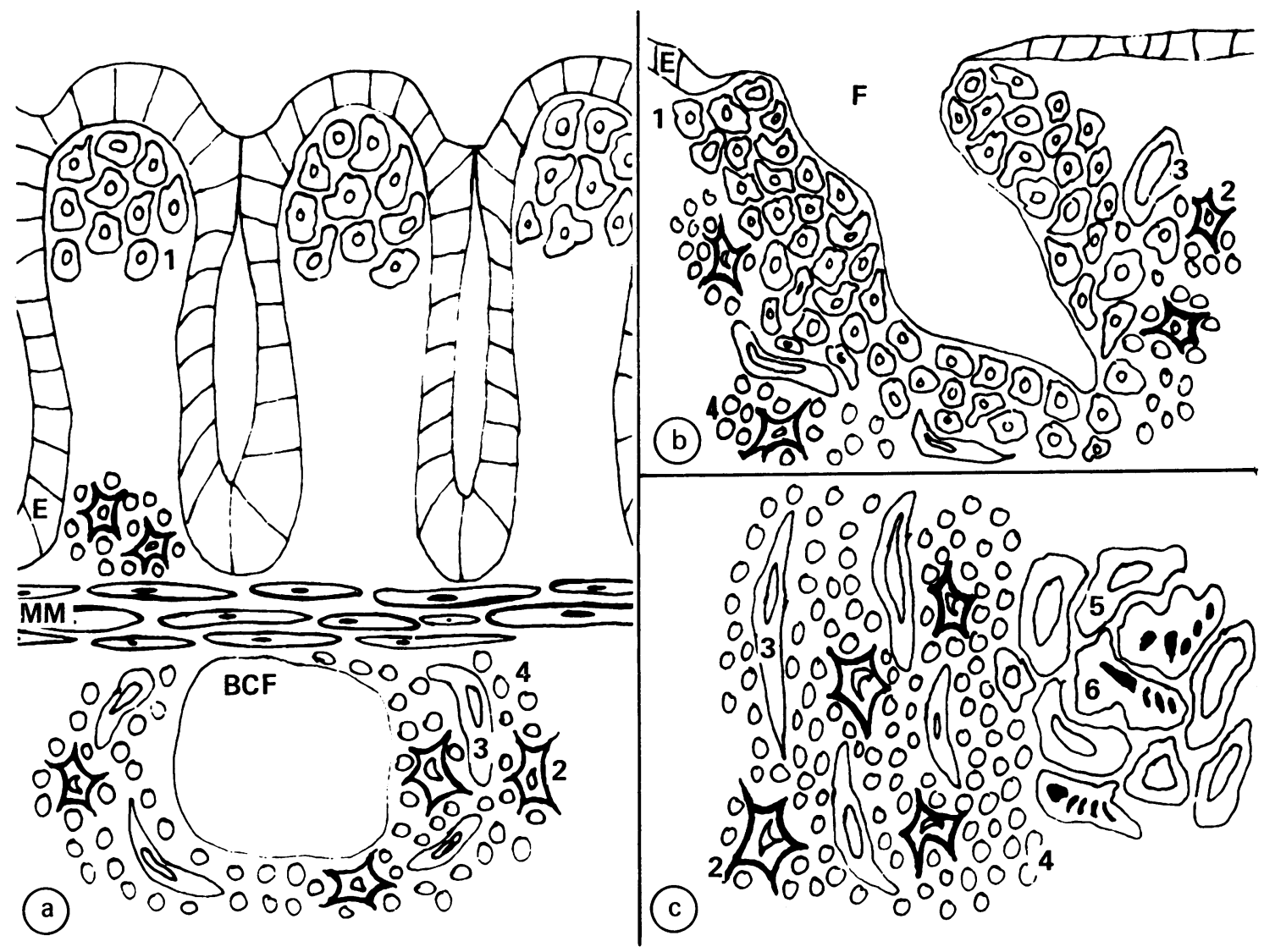

Fig 3 Schematic illustration of localisation of scavenger macrophages and dendritic cells in: (a) normal colon (b) the surrounding of fissures in $C D$ (c) granulomas. $1=$ scavenger macrophage, $2=$ dendritic cell, $3=$ high endothelial venule, $4=$ lymphocyte, $5-6=$ epithelioid cell, $B C F=B$ cell follicle, $E=$ epithelium, $M M=$ muscularis mucosae.

scattered diffusely throughout the lamina propria. Their use of histochemical criteria and mucosal biopsies may have played a role again in the discrepancy between theirs and our data. Further a strong overlap of 'their dendritic cells' with 'our undeterminate monocytoid cells' is probably also the case. (We found many 'undeterminate monocytoid cells' present in the submucosal tissue.)

In conclusion dendritic cells (CD11 + , Heca-452+, RFD1+, AP-) and scavenger macrophages (CD11+, Heca-452-, RFD1-, AP+) could be identified in situ in normal and diseased gut wall. They form the extremes in a spectrum of gut mononuclear phagocytes.

Dendritic cells were predominantly identified in highly organised lymphoid tissue, present at the deeper layers in the gut wall (normal gut: underneath the muscularis mucosae; surrounding the broad zone of scavenger macrophages at the bottom of ulcers
(CIBD) and fissures (CD), and adjacent to the granulomas (CD). These observations can be taken as evidence that exaggerated antigen handling and presentation and stimulation of the immune response takes place at these foci. The factual presence of these granulomas in CD and their position adjacent to lymphatics as far as the serosal layer and the mesenteric lymph node indicates that the antigens to be handled in this disorder are extremely difficult to degrade. The observation that scavenger macrophages were localised more superficially, as band like zones (in normal gut: subepithelial; mainly surrounding ulcers (CIBD) and fissures (CD)) can be taken as evidence that at these sites there is an exaggerated exposure to and degradation of foreign material.

The differences in pattern of scavenger macrophages and dendritic cells between normal and diseased gut are mainly quantitative. Functional studies should be undertaken, however, to analyse if 


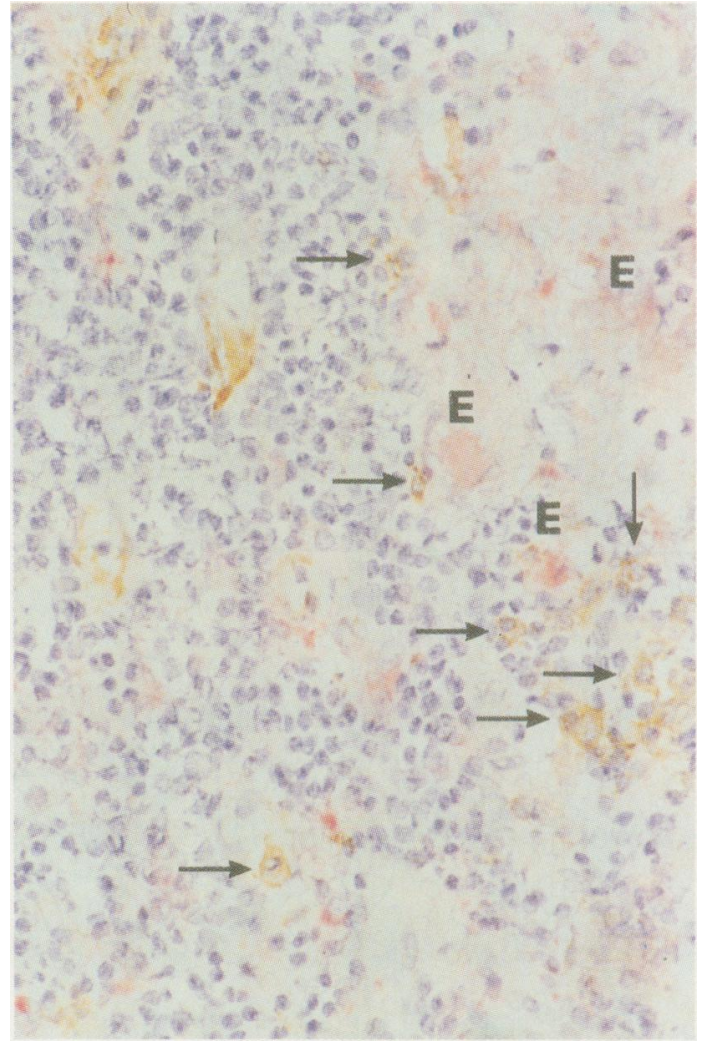

Fig 4 Composition of a granuloma in $C D$. Epithelioid cells $(A P+)$ in the centre, surrounded by a zone of Tlymphocytes with some HEV's (Heca$452+)$, intermingled with dendritic cells $(A P-$, Heca452+); E=epithelioid cell, $\rightarrow=$ dendritic cell. Immunoperoxidase double staining for AP and Heca452 .

there is no defect in the function of these particular cell types.

The authors would like to express their appreciation to L Poulter, for his gift of the monoclonal antibody RFD1, M J E Koopmans, J G de Windt, M de HaanMeulman, J T van Velthuizen, and G J Oskam for their technical assistance. This study has been presented at the Digestive Disease Week and the 89th Annual meeting of the American Gastroenterological Association in New Orleans, Louisiana (USA) during May 14-18, 1988, and is published in abstract form in Gastroenterology 1988; 94: A418.

\section{References}

1 Unanue ER, Beller DI. Lu CY. Allen PM. Antigen presentation: comments on its regulation and mechanism. $J$ Immunol 1984; 132: $1-5$.
2 Balfour BM, Drexhage HA, Kamperdijk EWA, Hoefsmit ECM. Antigen-presenting cells, including Langerhans cells, veiled cells and interdigitating cells. In: Porter R. Whelan J, eds. Microenvironments in haemopoietic and lymphoid differentiation. Ciba Foundation Symposium 84. London: Pitman Books Ltd, 1981: 281-301.

3 Silberberg-Sinakin I, Thorbecke GJ, Baer RL, Rosenthal SA, Berezowsky V. Antigen-bearing Langerhans cells in skin, dermal lymphatics and in lymph nodes. Cell Immunol 1976; 25: 137-51.

4 Poulter LW, Janossy G. The involvement of dendritic cells in chronic inflammatory discase. Scand J Immunol 1985; 21 : 401-7.

5 Wilders MM, Drexhage HA, Kokjé, Verspaget HW. Meuwissen SGM. Veiled cells in chronic idiopathic inflammatory bowel disease. Clin Exp Immunol 1984; 55: $377-87$.

6 Poulter LW. Review; antigen presenting cells in situ: their identification and involvement in immunopathology. Clin Exp Immunol 1983; 53: 513-20.

7 Mishra BB, Poulter LW, Janossy G, Geraintjames D. The distribution of lymphoid and macrophage-like cell subsets of sarcoid and Kveim granulomata: possible mechanism of negative PPD reaction in sarcoid. Clin Exp Immunol 1983; 54: 705-15.

8 Poulter LW, Duke O, Hobbs S, Janossy G, Panay G. Seymour G. The involvement of interdigitating (antigen-presenting) cells in the pathogenesis of rheumatoid arthritis. Clin Exp Immunol 1983; 51: 24754.

9 Janossy G, Duke O. Poulter LW, Panayi G, Bofill M. Goldstein G. Rheumatoid arthritis: a disease of Tlymphocyte/macrophage immunoregulation. Lancet 1981; ii: 839-42.

10 Meijer CJLM, de Graaf-Reitsma CB, Lafeber GJM. Cats A. In situ localisation of lymphocyte subsets in synovial membranes of patients with rheumatoid arthritis with monoclonal antibodies. J Rheumatol 1982; 9: 359-65.

11 Selby WS, Poulter LW, Hobbs S, Jewell DP, Janossy G. Heterogenity of HLA-DR positive histiocytes in human intestinal lamina propia: a combined histochemical and immunohistological analysis. J Clin Pathol 983; 36: 37984.

12 Duijvestijn AM, Horst E, Pals ST, et al. High endothelial differentiation in lymphoid and inflammatory tissues defined by monoclonal antibody HECA452. Am J Pathol. 1988; 130: 147-55.

13 Horst E, Pals ST. Duijvestein AM, et al. Expression and regulation of an antigen specific for endothelium in human lymphocyte homing. Adv Exp Med Biol. (In press).

14 Poulter LW, Campbell DA, Munro C, Janossy G. Discrimination of human macrophages and dendritic cells by means of monoclonal antibodies. Scand $J$ Immunol 1986; 24: 351-7.

15 Collings LA, Waters MFR, Poulter LW. The involvement of dendritic cells in the cutaneous lesions associated with tuberculoid and lepromatous leprosy. Clin Exp Immunol 1985; 62: 458-67.

16 Korelitz BI, Present DH,. Alpert LI, Marshak RH, 
Janowitz HD. Recurrent regional ilcitis after ilcostomy and colectomy for granulomatous colitis. N Engl J Med 1972; 287: 110-5.

17 Whitehead R. Major problems in pathology. Vol 3; Mucosal biopsy of the gastrointestinal tract. Philadelphia: W B Saunders Company, 1985.

18 Mason DY, Abdulaziz Z, Falini B, Stein H. Double immunoenzymatic labelling. In: Polak JM, van Noorden S, eds. Immunocytochemistry. Practical applications in pathology and biology. Bristol: Wright \& Sons Ltd, 1983: 113-28.

19 Pearse, AGE. Histochemistry. Theoretical and applied. Vol 1. Edinburgh: Churchill Livingstone, 1980.

20 Morgan KL. Johne's and Crohn's: Chronic inflammatory bowel discase of infectious aetiology? Lancet 1987; i: $1017-9$.

21 Thayer WR, Coutu JA, Chiodini RJ, Van Kruiningen HJ, Merkal RS. Possible role of mycobacteria in inflammatory bowel disease. Mycobacterial antibodies in Crohn's disease. Dig Dis Sci 1984; 29: 1080-5.

22 Chiodini RJ, Van Kruiningen HJ, Thayer WR, Merkal RS, Coutu JA. Possible role of mycobacteria in inflammatory bowel disease. An unclassified Mycobacterium species isolated from patients with Crohn's disease. Dig Dis Sci 1984; 29: 1073-9.

23 McCaffery TD, Kraft SC, Rothberg RM. The influence of different techniques in characterizing human antibodies to cow's milk proteins. Clin Exp Immunol 1972; 11: 225-34.

24 Taylor KB, Truelove SC, Wright R. Serologic reactions to gluten and cow's milk proteins in gastrointestinal discase. Gastroenterology 1964; 46: 99-108.

25 Perlmann P, Hammerström S, Lagercrantz R, Campell D. Autoantibodies to colon in rats and human ulcerative colitis: cross reactivity with Escherichia Coli 0:14 antigen. Proc Soc Exp Biol Med 1967; 125: 975-80.

26 Wang CY, Good RA, Ammirati P, Dymbort G, Evans RL. Identification of $\mathrm{p} 69,71$ complex expressed on human T-cells sharing determinants with B-type chronic lymphocytic leukemic cells. J Exp Med 1980; 151: 153944.

27 Nadler LM, Anderson LD, Martl G. B4, a human B lymphocyte-associated antigen expressed on normal mitogen-activated, and malignant B lymphocytes. J Immunol 1983; 131: 244-50.

28 Evans RL, Wall SW, Platsoucas CO, et al. Thymusdependent membrane antigens in man: inhibition of cell-mediated lympholysis by monoclonal antibodies to TH2 antigen. Proc Natl Acad Sci USA. 1981; 78: 544-8.

29 Ledbetter JA, Evans RL, Lipiaki M, Rundles C, Herzenberg LA. Evolution conservation of surface molecules that distinguish $\mathrm{T}$ lymphocytes helper/inducer and cytotoxic suppressor subpopulations in mouse and man J Exp Med 1981; 153: 310-23.

30 Lampson LA, Levy $R$. Two populations of Ia-like molecules on a human B cell line. J Immunol. 1980; 125: 293-9.

31 Jansen J, Falkenberg JHF, Stepan DE, Lebien TW. Removal of neoplastic cells from autologous bone marrow grafts with monoclonal antibodies. Semin Hematol 1984; 21 : 164-81. 